This item was submitted to Loughborough's Research Repository by the author.

Items in Figshare are protected by copyright, with all rights reserved, unless otherwise indicated.

\title{
Guest editorial special issue on pulsed power science and technology
}

PLEASE CITE THE PUBLISHED VERSION

https://doi.org/10.1109/TPS.2018.2867710

PUBLISHER

(c) IEEE

VERSION

AM (Accepted Manuscript)

LICENCE

CC BY-NC-ND 4.0

REPOSITORY RECORD

Bayne, Stephen, Bucur Novac, Heather O'Brien, and Hua Li. 2019. "Guest Editorial Special Issue on Pulsed Power Science and Technology”. figshare. https://hdl.handle.net/2134/35455. 


\section{Guest Editorial \\ Special Issue on Pulsed Power Science and Technology}

This special issue of the IEEE Transactions on Plasma Science (TPS) mainly contains works presented at the $21^{\text {st }}$ IEEE International Pulsed Power Conference (PPC) held in Brighton, United Kingdom, between 18-22 June 2017 (http://ece-events.unm.edu/ppc2017/). This conference marks an important step, as it was located for the first time outside the USA. The PPC is well known for serving the Pulsed Power and Plasma Science communities as the principal forum for the professionals worldwide, where the most important technical presentations and discussions are taking place and the Brighton conference made no exception. The $21^{\text {st }}$ PPC was extremely successful, with 470 quality papers submitted as equal contributions from the Americas, Europe, and Asia.

The areas of Pulsed Power and Plasma Science have seen a significant growth over the years, with many new applications being now considered by a large number of laboratories worldwide. This Special Issue brings the most up-to-date developments and research results in the areas of Pulsed Power and Plasma Science to the readers of the IEEE TPS. In this way the Special Issue serves as a forum for researchers in the domains of Pulsed Power and Plasma Science where they can submit high impact research journal papers for peer review. This Special Issue focuses on the following range of topics, which were also the focus areas for the PPC 2017:

1. Fundamental Research and Basic Processes

2. Microwave Generation and Plasma Interactions

3. Charge Partial Beams and Sources

4. High Energy Density Plasmas and Applications

5. Pulsed Power Switches and Components

6. Industrial, Commercial, and Medical Applications

7. Electromagnetic Launch

8. Pulsed Power Sources

9. Pulsed Power Systems

10. Diagnostics

Like any special issues in the past, this Special Issue collects and chronicles the latest technological and theoretical advances and provides an archive of the state-of-the-art research and technologies in the fields of pulsed power and plasma science. The Special Issue includes a total of 58 peer reviewed papers with a strong international participation. There is also diversity within the constituent scientific community, which is reflected in the participating institutions that includes universities, industry, and governmental research laboratories.

The Guest Editors team would like to thank the authors for their contributions to this Special Issue. The papers are all well written and will certainly have a significant impact in the pulsed power and plasma physics domains. The Guest Editors team would also like to thank all the referees for their great work as volunteers for reviewing the numerous manuscripts in a timely manner. Without their hard work, 
dedication, and responsiveness, this Special Issue would not be published in time nor at the present high level of quality. The Guest Editors team would also like to thank the Editor-in-Chief, Steve Gitomer, for his guidance and patience during the long and tedious review process. Additionally, the Guest Editors team would also like to thank Professor Weihua Jiang, the Senior Editor. This publication would not have been completed in a timely manner without the hard work, dedication, and leadership of Professor Jiang. His guidance to the Guest Editor team made their job easier, more focused and at the same time increased the quality of the Special Issue. Finally, the Guest Editors team would like to extend thanks and appreciation to the members of the IEEE Nuclear and Plasma Science PPST and PSA Committees for their continuous support.

Stephen Bayne, Guest Editor

Electrical and Computer Engineering Department

Texas Tech University

Lubbock, TX 79423, USA

Bucur Novac, Guest Editor

Wolfson School of Mechanical, Electrical, and Manufacturing Engineering

Loughborough University

Leicestershire, LE11 3TU, UK

Heather O'Brien, Guest Editor

Army Research Lab

Adelphi, MD, 20783, USA

Hua Li, Guest Editor

School of Electrical and Electronic Engineering

Huazhong University of Science and Technology

Wuhan 430074, China 